\title{
Efficiency Determinants of Islamic Insurance in Indonesia
}

\author{
Rachma Indrarini ${ }^{1}$, Clarashinta Canggih ${ }^{1}$, and Sylva Alif Rusmita ${ }^{2}$ \\ ${ }^{1}$ Economic Faculty, State University of Surabaya \\ ${ }^{2}$ Department of Islamic Economic, Airlangga University Surabaya
}

\section{Abstract}

This paper aims to divulge Islamic Insurance company efficiency and factors affect it. This paper uses quantitative approach using DEA (Data Envelopment Analysis) to assess efficiency and Linear Regression to analyze factors affected it. Input Variables of this paper are Total Asset, Expenses and Claim payment, whereas output variables are income and tabarru fund within the period of 2012-2016. Objects of this research are Asuransi Syariah Al - Amin, Takaful and Asuransi Syariah Amanah Gita. The result showed that in 2012 Asuransi Syariah Al-Amin, Asuransi Syariah Amanah Gita, and Takaful reached 100\% efficiency. In 2013, 2014, 2015 both Asuransi Syariah Al-Amin

Corresponding Author: Rachma Indrarini rachmaindrarini@unesa.ac.id

Received: 10 February 2019 Accepted: 14 March 2019 Published: 28 March 2019

Publishing services provided by Knowledge E

(c) Rachma Indrarini et al. This article is distributed under the terms of the Creative Commons Attribution License, which permits unrestricted use and redistribution provided that the original author and source are credited.

Selection and Peer-review under the responsibility of the ICIEBP Conference Committee.

\section{G OPEN ACCESS} and Takaful reached above 50\% efficiency, while Asuransi Syariah Amanah Gita only reached under 50\% efficiency. Meanwhile in 2016 both Asuransi Syariah Al-Amin and Takaful reached 100\% efficiency, while Asuransi Syariah Amanah Gita only reached above 50\% efficiency. Furthermore, it showed that only ROE and LNTA significantly affect efficiency.

Keywords: ISLAMIC INSURANCE, EFFICIENCY, ROE, LNTA, TER

\section{Introduction}

Generally Islamic Financial industry in Indonesia can be divided into two groups, bank and non-bank. However, up to this time Islamic bank still dominates Islamic Financial Industry in Indonesia compares to its counterpart. The growth of non-bank financial institution is still unstable.

Insurance appears as one of people basic need as a life protection. However, insurance contains uncertainties and is deemed not in accordance with Islamic principles. Hence, the need for Islamic insurance arises to meet the needs of people, particularly Muslim. The first Islamic insurance company established in Indonesia was Syarikat Takaful Indonesia in 1994.

Despite of its necessity, the development of Islamic Insurance industry in Indonesia is not as good as expected. As one of non-bank Islamic financial institution, since its 
establishment in 1994 until December 2017, there are 13 full-fledged Islamic insurance companies and 50 Islamic units with total asset around IDR 40 billion (OJK, 2017).

Issuance of POJK No 67/POJK.05/2016, that command all Islamic insurance to spin off of its conventional parent company in 2024 at the latest, as well as the development and competition inside insurance industry, both Islamic and conventional, coerce Islamic insurance company to optimize its performance. Efficiency is one of the tools to measure company performance. Efficiency consist of technical efficiency, which reflect company capability to maximizing output with certain input, and allocation efficiency, which reflects company ability to utilizing input optimally in certain price level, these two sizes are then combined into economic efficiency (total) (Kusuma, 2008). Furthermore, there are input-oriented measures, which shows number of input that can be reduced proportionally without reducing output, and output oriented measures, which measures escalation of output proportionally without changing the number of input usage (Kusuma, 2008). Tuffahati, Mardian, Suprapto (2017) and Sabiti, Effendi, Novianti (2017) mentioned that efficiency measurement can be used to asses Islamic insurance company performance that will determine industry competitiveness, which in turn can increase public trust.

Islamic insurance companies in Pakistan were more efficient rather than the conventional one (Khan and Noreen, 2014). While in Malaysia conventional insurance companies performed better efficiency than takaful companies in 2011 (Antonio et all, 2013).

However, in Indonesia there was none of full-fledged Islamic insurance that had reached optimum efficiency while in Islamic unit there are 2 general insurance companies and 4 life insurance companies that had reached efficiency

Sabiti, Effendi, Novianti (2017) analysis 14 sharia insurance companies and 12 sharia general insurance companies in the period 2013-2015 in Indonesia. The method used is DEA with three input variables, namely assets, expenses, payments, and two output variables, namely tabarru income and funds obtained. The result is sharia life insurance and general Islamic insurance in Indonesia have not yet reached an efficient level and said that there was none of Islamic General Insurance Company as well as Islamic Life Insurance Company that had reached efficiency.

Rudiansyah (2017) used DEA analysis at life insurance in Indonesia with 8 object life insurance. By using three input variables cost of commissive, operational cost, total equity and two output variables Premium and Investment Revenue the result show that only 15\% Life insurance in Indonesia that achieve 100\% efficient. 
Abduh (2012) used input variables, such as commission fees and management costs, while the output variables are premium receipts and investment income. The research results show that conventional insurance is less efficient than Islamic insurance. The reason for this is because Islamic insurance has different products but is operated under the same financial system as conventional insurance.

The other researcher used total assets, general and administrative expenses, and claim payments as an input, while the output is investment income and tabarru funds (Sunarsih, Fitriyani, 2018). Mean while, variable inputs (Assets, Expenses and Claim Payments) and their output (tabarru funds and income) Benarda (2016).

Some another researcher use different analysis to determine factor that influence Islamic Insurance efficiency. For example, the drive for market share, firm size and the ratio of equity (ROE) to total invested assets are important determinants of an insurance firm's efficiency. (Kwadjo, 2012)

Luhnen (2009) analyse six efficiency determinants; size, distribution systems, ownership, specialisation, leverage and growth. A positive relationship was found to exist between size and efficiency.

So far, research about efficiency in Islamic Insurance Company only discuss about efficiency level as well as efficiency comparisons. There is view research about efficiency determinants of Islamic Insurance Company. Hence this research aims to find out internal factors that affect efficiency of Islamic Insurance Company in Indonesia.

\section{Method}

This research used quantitative approach. In order to measure efficiency level, this research used Data Envelopment Analysis (DEA). This research measured technical efficiency with output oriented measurement. Efficiency was measured through input variable based on previous study, they are: total asset, insurance cost and claim, for the output variable income and tabarru' fund.

Meanwhile, to project the efficiency determinants this research used Linear Regression Analysis. Dependent variable was Efficiency level from DEA result and independent variables were profit (Return on Equity), Expenses ratio (Total Expenses Ratio), and size (logarithm natural of total asset).

Here is the regression model

$$
Y=\alpha+\beta 1 X_{1}+\beta 2 X_{2}+\beta 3 X_{3}+e i
$$

$Y=$ Intermediation efficiency 
$\beta=$ Coefficient value of each independent variable

$\alpha=$ Constanta

$\mathrm{X}_{1}=\mathrm{ROE}$ (Return on Equity)

$\mathrm{X}_{2}=$ LnTA (logarithm natural of total asset)

$\mathrm{X}_{3}=$ TER (Total Expenses Ratio)

ei $=$ the residual model that follows a normal censored distribution

The hypothesis is Return on Equity (ROE), Expenses ratio (TER), and logarithms natural of total asset (LNTA) are having significant effect to Efficiency.

This research used secondary data from financial report of 3 insurance companies in the period of 2012-2016. Those companies are Asuransi Syariah Takaful, Asuransi Syariah Al - Amin and Asuransi Syariah Amanah Ghita.

\section{Result and Discussion}

In order to know the level of efficiency, input variable (total asset, insurance cost and claim) and output variable (income and tabarru' fund) are processed using DEA. However, from the data collection it is found that data of claim from Asuransi Al Amin in 2012 and 2013 as well as Asuransi Syariah Amanah Ghita in 2012 is null. Furthermore, data from tabarru' fund from Asuransi Syariah Al Amin in 2012 and 2013 as well as Asuransi Syariah Amanah Ghita in 2012 is also null. Hence, claim and tabarru fund are being taken out from variable input and output.

Following table is the result of data processing using DEA

TABLE 1: Efficiency Result.

\begin{tabular}{l|c|c|c|c|c|}
\hline & 2012 & 2013 & 2014 & 2015 & 2016 \\
\hline $\begin{array}{l}\text { Year } \\
\text { Efficiency }\end{array}$ & 100 & 94.96 & 68.97 & 66.44 & 100 \\
\hline $\begin{array}{l}\text { Asuransi Syariah } \\
\text { Al Amin }\end{array}$ & 100 & 16.68 & 32.53 & 26.5 & 66.75 \\
\hline $\begin{array}{l}\text { Asuransi Syariah } \\
\text { Amanah Ghita }\end{array}$ & 100 & 90.98 & 92.94 & 93.38 & 100 \\
\hline $\begin{array}{l}\text { Takaful } \\
\text { Source: data processed }\end{array}$ & & & & \\
\hline
\end{tabular}

From the table above, it can be seen that most of Islamic insurance companies is still inefficient. It showed that from 5 years operational of each company, it only got efficiency score of 100 in one or two years. All of the companies reach score of 100 in 2012, during 2013-2015 is decline for Asuransi Syariah Al Amin, and fluctuate for 
Asuransi Syariah Amanah Ghita and Takaful. While on 2016, Asuransi Syariah Al Amin, and Takaful reach the score of 100 . The result is in line with findings from several studies. Sunarsih and Fitriyani (2018) mentioned that during 2014-2016, four Islamic Insurance Companies (Asuransi Central Asia, Asuransi Staco Mandiri, Asuransi Umum Mega dan Asuransi Sunlife) are inefficient due to its administrative and general cost, claim payment, capital investment, investment return, and tabarru' collection.

The efficiency score is used as an efficiency determiner which is processed to divulge the efficiency determinant as follows.

TABLE 2: Efficiency determinant.

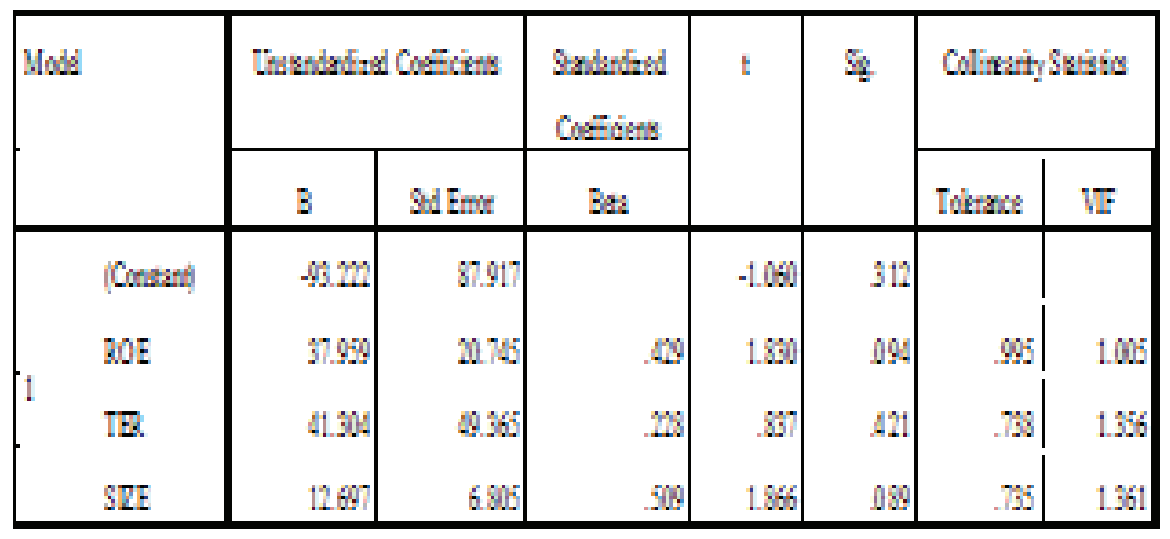

From the table above it showed that ROE and LNTA (size) significantly affect efficiency. As for TER, it does not affect efficiency of Islamic Insurance Company. ROE, as a part of profitability analysis, provide information about the ability of the company to precede its equity into profit. The result showed that ROE significantly affect efficiency, therefore the higher the ROE the more efficient the company. Greene and Segal (2004) found that ROE has negative correlation with company inefficiency, hence more efficient insurance company showed higher ROE. Akhtar (2018) showed that profitability is one of important determinants of efficiency. Furthermore Abd. Karim (2005) stated that on average efficient firms have higher returns on equity. Therefore, in order to be more profitable an insurance company has to increase its efficiency.

Size of the insurance company, described with LNTA, has significant impact toward Islamic Insurance Company efficiency. The larger the insurance company, the more efficient. It is in line with the findings of Luhnen (2008) that size has positive relationship with efficiency of the firm. The larger the firm size result the higher the efficiency. Afza and Asghar (2010) said that on average the larger the size of non-life insurers the more technically efficient the company. Larger insurers were more efficient than medium and small sized insurers. This finding suggest that larger insurance company, particularly Islamic ones, has relatively more expertise who could support it to reach its operational 
improvements (Kader et all, 2010). Moreover, larger insurance company is likely more trustable and reliable to customers since reliability, trust, and size are believed have a close relationship particularly in insurance company that less predictable and lot uncertainty (Ansah-Adu et all, 2011)

\section{Conclusions}

From the data processed, it showed that the efficiency level is varies of each Islamic Insurance Company. However most of the company does not reach maximum score yet. During the year of 2012 Asuransi Syariah Al Amin, Asuransi Syariah Amanah Ghita and Takaful reach score of 100, but during 2016 only Asuransi Syariah Al Amin and Takaful reach efficiency score of 100. The efficiency measurement is relative. There is possibility that the efficiency result will be changed when the observation year is extended. Islamic Insurance companies in Indonesia should publish their annual report to improve accountability as well as to provide data to public. Islamic insurance companies should improve its input and output variable to enhance its efficiency. ROE and LNTA (firm size) affect efficiency of Islamic Insurance Company. The higher the ROE and the bigger the size of the Islamic Insurance Company, the closer it is to being efficient.

\section{References}

[1] Abd Karim, Mohd Zaini. 2005. Cost efficiency and profitability in Thailand's life insurance industry: A stochastic cost frontier approach. International Journal of Applied Econometrics and Quantitative Studies , 2-4. pp. 19-36.

[2] Abduh, M., Omar, M. A., \& Tarmizi, R. M. (2012). The Performance of Insurance Industry in Malaysia: Islamic vis-à-vis Conventional Insurance. Journal of Is/amic Banking \& Finance, 29(4).

[3] Afza, Talat \& Asghar, Muhammad. (2010). Firm Size and Efficiency in The Non-Life Insurers of Pakistan. Journal of Quality and Technology Management. VI(11): 165-183. Available at SSRN: https://ssrn.com/abstract $=2026360$

[4] Akhtar, Mohammad Hanif (2018). Performance analysis of Takaful and conventional insurance companies in Saudi Arabia. Benchmarking: An International Journal, Vol. 25 Issue: 2, pp.677-695, https://doi.org/10.1108/BIJ-01-2017-0018

[5] Ansah-Adu, Kwadjo, Andoh, Charles, and Abor, Joshua (2011). Evaluating the cost efficiency of insurance companies in Ghana. The Journal of Risk Finance. Vol. 13 
Issue: 1, pp.61-76, https://doi.org/10.1108/15265941211191949

[6] Antonio, Muhammad Syafii., Ali, Mohammad Mahbubi., Akbar,Nasr. 2013. A Comparative Analysis of The Efficiency of Takaful And Conventional Insurance in Malaysia. International Journal of Excellence in Islamic Banking and Finance, Volume: 3 Issue: 1

[7] Benarda, B., Sumarwan, U., \& Hosen, M. N. (2016). Tingkat efisiensi industri asuransi jiwa syariah menggunakan pendekatan Two Stage Data Envelopment Analysis. Jurnal Aplikasi Bisnis dan Manajemen (JABM), 2(1), 64.

[8] Greene, William H., Segal, Dan. 2004. Profitability and Efficiency in the U.S. Life Insurance Industry. Journal of Productivity Analysis, 21(3): 229-247. Available at: https://www.jstor.org/stable/41770157

[9] Kader, H.A, Adams, M. \& Hardwick, P. 2010. The Cost Efficiency of Takaful Insurance Companies. The Geneva Paper on Risk and Insurance- Issues and Practice, Volume 35 Issue 1 pp:161-181

[10] https://doi.org/10.1057/gpp.2009.33

[11] Khan, A., Noreen, U. 2014. Efficiency Measure of Insurance vs Takaful Firms Using DEA Approach: A Case of Pakistan. Journal Islamic Economic Studies, Vol. 22 No.1, May 2014 (139-158).

[12] Kusuma wardani Deni, Tri hariyanto. 2008. Tingkat Kesehatan Dan Efisiensi Bpr Jatim. Majalah ekonomi tahun xviii no. 2 agustus 2008

[13] Luhnen, M. 2008. Determinants of efficiency and productivity in German propertyliability insurance: evidence for 1995-2006. Working Papers on Risk Management and Insurance No. 63.

[14] Miniaoui, H., Chaibi, A. 2014. Technical Efficiency of Takaful Industry: A Comparative Study of Malaysia and GCC Countries. Working Paper Series IPAG Bussiness School.

[15] Noor Mohammad, et.al. 2011. Relationship Between Islamic Banking Profitability And Determinants Of Efficiency. The IUP Journal Of Managerial Economics, Vol IX, No.3 2011

[16] Rusydiana, A. S., \& Nugroho, T. (2017). Measuring Efficiency of Life Insurance Instution in Indonesia: Data Envelopment Analysis Approach. Global Review of Islamic Economics and Business, 5(1), 012-024.

[17] Sabiti MB, Effendi J, Novianti T. 2017. Efisiensi Asuransi Syariah di Indonesia. Jurnal Al-Muzara'ah, Vol.5, No.1.

[18] Sunarsih, Fitriyah. 2018. Analisis Efisiensi Asuransi Syariah di Indonesia tahun 2014-2016 dengan metode Data Envelopment Analysis (DEA). Jurnal Ekonomi \& Keuangan Is/am, 4(1):9-21. doi 10.20885/JEKI.vol4.iss1.art2 
[19] Tuffahati, H., Mardian, S., Suprapto, E. 2017. Pengukuran Efisiensi Asuransi Syariah Dengan Data Envelopment Analysis (DEA). JURNAL AKUNTANSI DAN KEUANGAN ISLAM, 4(1). Retrieved from https://jurnal.sebi.ac.id/index.php/jaki/article/view/59

[20] Biener, Christian, Eling, Martin, and Wirfs, Jan Hendrik. 2015. The determinants of efficiency and productivity in the Swiss Insurance industry, European Journal of Operational Research. doi:10.1016/j.ejor.2015.07.055 